\title{
The Labour Market Situation in the Central-Eastern European Region - Towards a New Labour Paradigm
}

\author{
Katalin Lipták ${ }^{1}$ \\ ${ }^{1}$ Institute of World- and Regional Economics, University of Miskolc, Miskolc, Hungary \\ Correspondence: Katalin Lipták, Institute of World- and Regional Economics, University of Miskolc, Miskolc, \\ Hungary. E-mail: liptak.katalin@uni-miskolc.hu
}

Received: July 4, 2013 Accepted: July 24, 2013 Online Published: August 7, 2013

doi:10.5539/jgg.v5n3p88 URL: http://dx.doi.org/10.5539/jgg.v5n3p88

\begin{abstract}
The author assumes that globalization and its regional and local impacts have an important role in nowadays' economics. An overview is given about the main findings of the economic theories associated with employment and paid work; reinterpretation of the concept of labour is also provided, divided into pre-industrial, industrial and post-industrial periods, which the author aligns with the periods of the economic thought. The author interprets globalization as a factor influencing the transition between industrial and post-industrial periods; and she elaborately introduces its economic-social and labour market impacts. Central-Eastern European countries and regions are analyzed, as the territorial unit of the research, from labour market and employment aspects. Special attention is paid to the comparative evaluation of the employment policy documents in the case of the investigated countries. The author also draws attention to the deficiencies of labour situation. Afterwards, she contributes suggestions to the criteria of creating a more efficient regional employment policy.
\end{abstract}

Keywords: new labour paradigm, globalization, regional disparities, Central-Eastern Europe

\section{Introduction}

\subsection{Introduce the Problem}

Paradoxically, challenges arising from the unification of the world have made the necessity for regional and local answers stronger. The idea of an economy strengthening social inclusion and representing more solidarity increasingly appears in the concept of sustainable development. The transformation of the labour market calls for the revaluation of the notion of labour; it puts the issue of employment in another perspective. The solution for globally existing lack of employment is more and more frequently sought focusing on sustainability and social inclusion at regional and local levels. The following questions arise:

1) What are those global impacts that underpin the transformation of labour markets?

2) What regional differences occur in the appearance of the challenges?

This research focuses on the temporal and spatial regularities of the level and structure of employment, its interactions with the processes of globalization and the employment strategies seeking solution to the problems in the regions of Central-Eastern Europe and Hungary. Hypotheses are formulated at the beginning of the research.

\subsection{Hypothesis}

Hypothesis 1 - about the global changes of labour mass and the necessity of the revaluation of labour concept:

This hypothesis suggests that it is globalization that has speeded up the crisis of labour-paradigm in Central-Eastern Europe in the past three decades.

Hyothesis 2 - about the labour market peculiarities of Central-Eastern Europe:

a) Hoover index suggests that the trend observed in the regional equalization of population and the number of employees in Central-Eastern European countries contradicts that in the Western countries.

b) According to this hypothesis, the temporal change of the Human Development Index in Central-Eastern European regions has brought about a regional realignment coupled with the weakening of human potential in the labour market. 
Hypothesis 3 - about the necessity of the regionally differentiated employment policy intervention:

The employment policy efforts of the Central-Eastern European countries follow the European employment patterns to an excessive extent, paying insufficient attention to the national characteristics.

\section{Literature Review}

\subsection{Labour-Paradigm Shifts in Economic Theories}

The purpose of the theoretical overview is to draw a complex picture of the development of the employment-related elements of the economic schools of thought, the main ideas and thoughts of the specific schools and their most significant representatives, their core element and factual statements, and, at the same time, the change of the labour concept. The author of this thesis has reviewed the following economic periods and labour-related theories (Table 1).

Table 1. Periods investigated and their main representatives

\begin{tabular}{|c|c|}
\hline Economic periods & The main representatives economists \\
\hline Mercantilist & Jean Baptiste Colbert (1619-1683) \\
\hline Physiocrat & Francois Quesnay (1694-1774) \\
\hline \multirow[t]{4}{*}{ Classical economics } & William Petty (1623-1687) \\
\hline & Adam Smith (1723-1790) \\
\hline & David Ricardo (1772-1823) \\
\hline & Karl Marx (1818-1883) \\
\hline \multirow[t]{2}{*}{ Neoclassical economics } & Alfred Marshall (1824-1924) \\
\hline & Arthur Cecil Pigou (1877-1959) \\
\hline \multirow[t]{3}{*}{ Austrian school } & Joseph Alios Schumpeter (1883-1950) \\
\hline & Heller Farkas (1877-1955) \\
\hline & Navratil Ákos (1875-1952) \\
\hline Keynesian era & John Maynard Keynes (1883-1946) \\
\hline New classical macroeconomics & Robert Lucas (1937- ) \\
\hline Institutional economics & Evsey Domar (1914-1997) \\
\hline \multirow[t]{2}{*}{ Evolutionary economics } & Joseph Alios Schumpeter (1883-1950) \\
\hline & Thorstein Veblen (1857-1929) \\
\hline Ortodox economics & Milton Friedman (1912-2006) \\
\hline
\end{tabular}

Source: own work on the basis of Mátyás, A. (1969).

\subsubsection{Concept of Work in Pre-Industrial Societies}

In prehistoric times people worked irregularly, 3 to 4 hours a day, necessary for their means of subsistence. Decent work at that time covered the range of useful social activities done voluntarily in and for the community. Ancient philosopher Aristotle posed the question as to what the essence of happiness was and what can be regarded as work. He argued that the essence of happiness was the actual work of man. "The specific work of man is nothing different from the sensible - or at least not insensible - activity of soul" (Aristotle, 1997:19).

In ancient societies social status was not determined by work, that had no value. Goods come from ownership and not from work. Ancient philosophers (Plato and Aristotle) also claimed that citizens did not have to work, there was a distinct social stratus for that purpose. Work gained a double interpretation: on the one hand, classical work was what slaves did and, on the other hand, it was also a work what citizens did as intellectual activity (Aristotle, 1997).

At the same time, one should not forget about the world of medieval guilds: assistants and workers working there also acted in a specific form of paid work Sewell calls this period "corporist world order" that determines the process-technical organization of production as the social organization of work. This world order regards craft as 
community property that provides employment only to the members of the community (Castel, 1998).

In medieval time the value of work was totally insignificant, it was almost classified into the group of obligatory bad; however, at the same time, Calvin put forth another interpretation of labour, at the end of the "dark Middle Age", according to which every form of doing work meant serving God.

\subsubsection{Labour Concept of the Industrial Societies}

William Petty (1623-1687), living in the $17^{\text {th }}$ century put forth view different from the mainstream approach of the mercantilist era; he suggested that land and labour are regarded as the source of wealth. Petty is considered to be the first creator of the labour theory of value; he argued that only specific types of labour can be seen as value creating work, such as that producing precious metal serving as the raw material of money (Mátyás, 1969).

Classical economise Adam Smith (1723-1790) claims that a society's economy depends on two factors: the proportion of population dealing with productive work and the productivity of labour determined by the division of labour. He linked the change of number of population to the amount of wage. He explains in his work (Smith, 1959): "In that early and rude state of society which precedes both the accumulation of stock and the appropriation of land, the proportion between the quantities of labour necessary for acquiring different objects, seems to be the only circumstance which can afford any rule for exchanging them for one another." Somewhere he mentions that agricultural labour creates a larger value than industrial labour.

David Ricardo (1772-1823) lived and worked in the period of the industrial revolution and studied, which made it possible to study the advanced capitalist conditions. He agreed with the Smithian natural order, however individual interest appeared as a class interest in his case. His theoretical system is pervaded by class antagonism that appeared between mainly between industrialists and landowners. He traced the categories of capitalist economy he studied back to the labour theory of value.

Thomas Malthus (1776-1834) agreed with the Smithian labour theory of value, however he claimed that labour cannot be regarded as the accurate and valid measure of the actual exchange value. He made difference between productive and unproductive labour, in his opinion both physiocrats and Smith agreed that productive labour results in wealthiness (Malthus, 1944).

The problem of exchange of same value (refining the Smithian thoughts) was solved by Karl Marx (1818-1883), in his book titled Capital, by making distinction between the concepts 'labour' and 'labour force'. He emphasized the useful nature of labour: "the value of labour force, as that of any other commodity, is determined by the working time necessary for the production, that is also the re-production, of this special commodity... which also means that the value of labour force is the value of means of subsistence necessary to maintain its owner" (Zalai, 1988:41). The Marxian concept of labour placed an emphasis on use-value which did not appeared in the definition of subsequent researchers. Furthermore, he wrote down that the simple moments of labour process is the expedient activity that is the labour itself, the object of labour and the means of labour. The worker worked under the control of the capitalist whom his labour belonged to an the given time. He divided the society into three parts: landowners, capitalist and worker. According to Marx (1955) labour also becomes commodity in a completely developed capitalist system. That means, the worker markets his or her labour force and working ability the price of which is the wage; in this way same values are exchanged.

Marx, in his letter written to Engels, made relatively new statements:

- he described the dual nature of labour (partly labour appearing in the value of the product and partly labour appearing in use-value) he investigated labour from both qualitative and quantitative perspectives,

- $\quad$ he considered labour force to be a commodity rather than labour,

- he investigated surplus value regardless of its forms of appearance.

Alfred Marshall (1842-1924), among neo-classical economists came to the conclusion that labour creates surplus over wages the worn-out value of work-assisting tools; however, this surplus is not given to the worker, it is taken away from him this is a problem of social distribution (Deane, 1997).

John Maynard Keynes' (1883-1946) approach contrasted Smith's views. The theorems of the neoclassical theory completely overturned due to the global economic crisis of 1919-1933; therefore the development of a new economic paradigm became necessary. Many associate the notion of total employment with Keynes' name, however, this category had appeared in the work of the neoclassical economists as well. In Keynes' work total employment could occur only at the time of the disappearance of involuntary unemployment. Keynes' ideas make state intervention necessary and possible in the labour market so that the level of unemployment can be 
kept low. "Even Keynes does not suggest that unemployment can totally be eliminated from developing economies. Structural and frictional unemployment are necessary products of healthy restructuring of the economy in Keynes' school as well” (Bánfalvy, 1989:52).

Social attitudes associated with work and the lack of work began changing in the $18^{\text {th }}$ century. Work was interpreted as a way to achieve wealth, whereas the lack of work was seen as the The medieval conviction related to the lack of work (that is, idleness is a sin) began to be replaced by the view that the lack of work causes an economic loss to both the individual and the society. Arendt (1958) properly gave a precise account of the development of paid work. "The sudden spectacular upward career of labour, that catapults it from the lowest row, the most disdained position to a precious one, so that it becomes the top-rated human activity, began when Locke discovered the source of all property in labour. Its triumphant advance continued when Adam Smith explicitly made it clear that labour is the source of all wealth. It reached its climax in Marx's system where labour became the source of all productive activity, moreover the expression of the human nature of man."

\subsubsection{Labour Concept of the Post-Industrial Societies}

Modern societies are rightly called the "society of paid work", however the term "labour society" also appears frequently in the literature. One can read about the crisis of paid work since the 1960s, its heyday was the first quarter century up until the first oil crisis. The crisis was not only about the change and transformation of the world of work, it was also about the atypical forms of employment becoming increasingly popular. Part of the society was excluded from the world of paid work after the period of industrialization, it can be regarded as nowadays' period as well. The beginning of the crisis of labour paradigm started with Arendt's (1958) statement: "what is ahead of us is a labour society that is running out of work that is from the only activity it is good at. What could be more terrible than that?" He likens paid work to slave work and not to a voluntarily undertaken activity of free man. Gorz suggested that the socially useful activity should be placed at the centre of the society instead of paid work. Beck spoke of civic work done in favour of the community (Csoba, 2010).

\section{Social and Economic Impacts of Globalization}

The author investigated globalization as an influencing factor that leads from the industrial period to the post-industrial one. Globalization basically determine regional processes and regional labour markets. Five elements can be captured from the various definitions that appeared in the works of several authors:

- dependence,

- revaluation of relations among countries,

- transformation of social relations,

- boom of trade, internalization,

- labour market changes,

The impacts of globalization on labour markets are complex and researchers investigate only certain segments. The increasing turmoil of labour markets not only enhances uncertainty and inequality but it causes a decline in the relative wages of unskilled workers as a whole. The main impact of globalization is manifested by the increase of elasticity of demand for labour. The following factors, among those influencing the demand for labour, resulting from the changed economic situation, exerted an impact on the global labour market in the 1980s. They can clearly be seen as the impact of globalization:

- slow-down of economic growth in the developed capitalist countries,

- decrease in investments,

- few job-creations,

- rapid growth of real wages,

- increase of raw material prices,

- role of international division of labour.

Factors influencing the supply of labour force:

- change in the demographic factor and activity rate,

- increased women's willingness to work,

- intensification of international migration. 


\subsection{Methdology of Hoover-Index}

The change in the mass of global labour force and the evolution of differences among continents and countries between 1991 and 2009 are illustrated by means of Hoover-index. It is one of the most widespread index to show regional disparities. The index expresses in percentages as to how much percent of a social-economic phenomenon has to be transferred among regional units so that its regional distribution becomes that of another (e. g. population).

$$
h=\frac{\sum_{i=1}^{n}\left|x_{i}-f_{i}\right|}{2}
$$

$\mathrm{x}_{\mathrm{i}}$ and $\mathrm{f}_{\mathrm{i}}$ are distribution ratios, to which the followings apply: $\sum_{i=1}^{n} x_{i}=100 \sum_{i=1}^{n} f_{i}=100$

Krugman index, analogous with Hoover index, is appropriate to compare the employment structure of two regional units, which does not divide the absolute value of the differences of the distribution by two, in this way the maximum value of the index can be 200. Its disadvantage is that the interpretation of the results obtained from it is cumbersome; Names Nagy et al. (2005) did not recommend its application.

\subsection{Result of Hoover-Index}

In the case of the Hoover index of global employment the number of population and employed has been compared (Figure 1). A significant decrease is observable after 1990 as a mainstream change, which indicates the regional equalization of people of working age and the population. The differences among countries have globally decreased since 1996, the equalization increased; it has become worldwide since 2002. At the same time, however, the disparities have strengthened since 2005 in the European Union, that is, the competition is intensifying within the Union, according to the results of the above calculations. The accession in the year 2004 changed the previous trend in the European Union; the two curves get separated from each other from 2006.

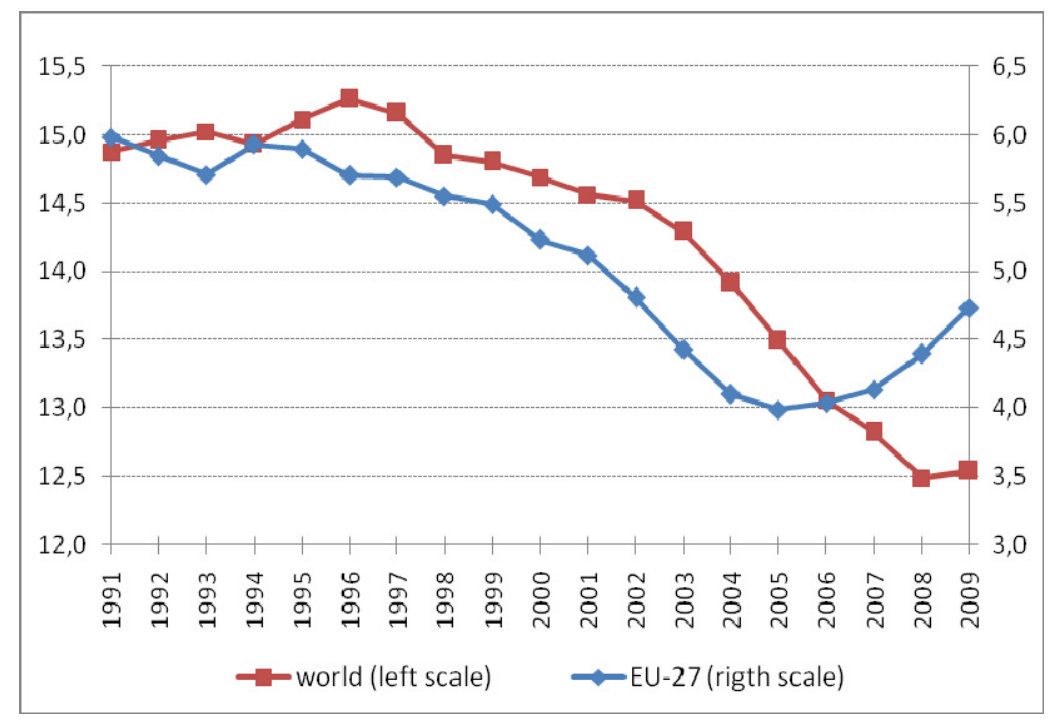

Figure 1. Evolution of Hoover index

Source: Own construction based on Worldbank data.

\subsection{Methodology of Hirschman-Herfindahl Index}

The author has calculated further regional disparity index as well in order to underpin her statements. The concentration index by Hirschman-Herfindahl is useful also in the measurement of the regional concentration of employment. 


$$
K=\sum_{i=1}^{n}\left(\frac{x_{i}}{\sum_{i=1}^{n} x_{i}}\right)^{2}
$$

$\mathrm{x}_{\mathrm{i}}$ is a regional a regional parameter given in a natural unit of measure in regional unit 'I' (Nemes Nagy, 2005).

\subsection{Result of Hirschman-Herfindahl Index}

The Hirschman-Herfindahl index indicates similar results to those of the Hoover index in terms of the regional concentration of the employed (Figure 2). The degree of concentration is below $30 \%$ in each period, however, in the case of the European Union, regional concentration of employment is significantly lower than in the countries of the world. In the case of the latter one can speak of a uniformly decreasing regional concentration up to 2008. At the same time, the period in question can be divided into three sub-periods, on the basis of the Hirschman-Herfindahl index, in the European Union. Regional concentration is stagnating between 1991 and 1994, decreasing between 1997 and 2003, slightly decreasing between 2003 and 2007, and finally increasing after 2007. These phases describing regional discrepancies are more equalized in the case of the Hoover index.

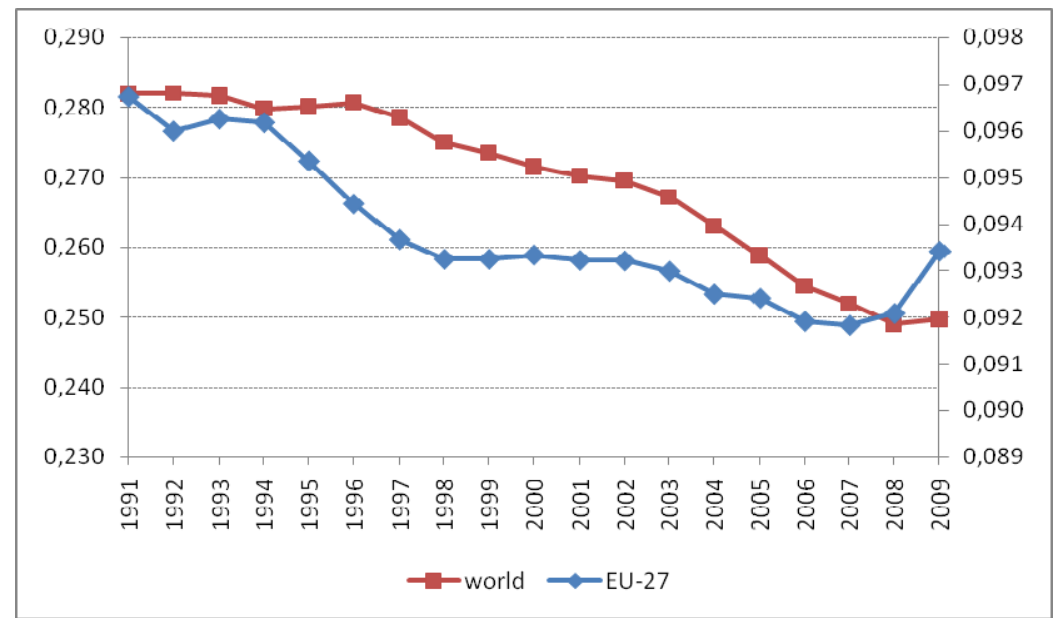

Figure 2. Evolution of Hirschman-Herfindahl index expressing the number of employed between 1991-2009 (\%)

Source: Own construction based on Worldbank data.

The conclusion can be drawn in the light of the regional inequality indices that the employment disparities decreased in the countries of the world between 1992 and 2009; whereas, in the European Union, the disparities have intensified since 2007 the concentration of labour force has grown since that time, the industrial sector is highly concentrated.

Thesis 1: It is necessary to re-define (paid) work in post-industrialist period, especially nowadays, because labour, interpreted as paid work is the privilege of a smaller social group in the transformation process accelerated by globalization; thus it is already not appropriate to completely fulfil its former social function.

\section{Investigation of the Central-Eastern-European Region's Labour Market Situation}

The author has strived to explore the regional peculiarities of Central-Eastern Europe in order to make the processes taking place in Northern Hungary more understandable. Having analyzed the Hoover index values between the population and the employed in EU-15 and Central-Eastern Europe, a special development path, that is lagging behind, of Eastern Bloc can be seen well, totally opposite processes take place (Figure 3). While competition is intensifying within EU-15 member states, the differences are apparently decreasing in Eastern countries; however it does not mean development or convergence, it rather means a joint divergence. A question arises here whether it is caused by the impact of the change of regime or the phase lag is of different nature. 


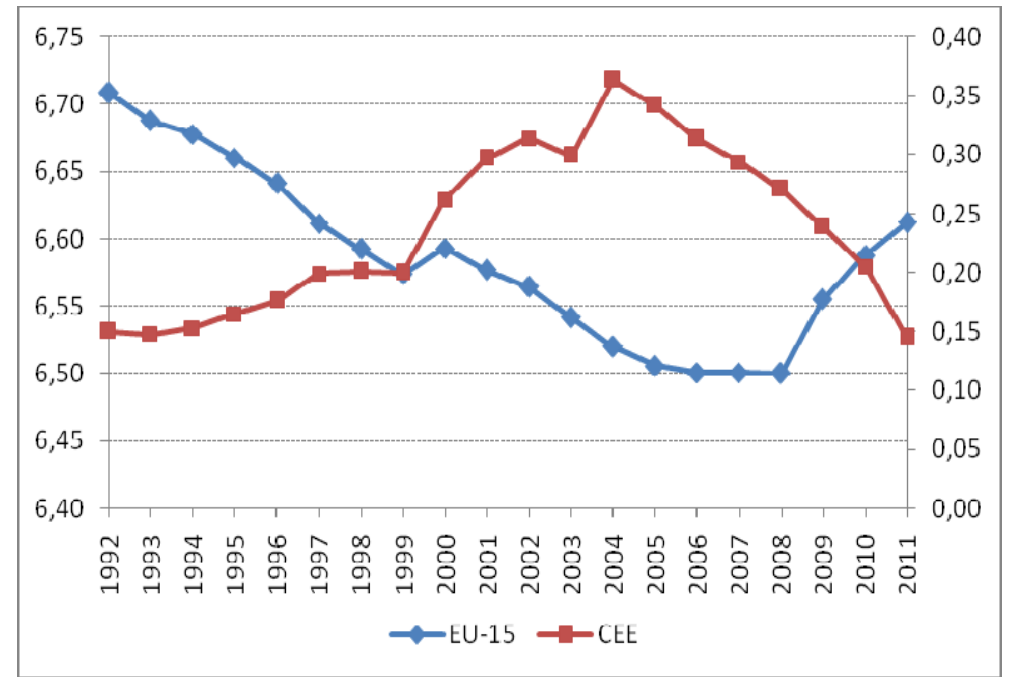

Figure 3. Evolution of Hoover-index in Europe (expressing population and employment)

Source: Own work (2013) based on Worldbank data.

Thesis 2.a) Labour market competition has intensifying since the expansion of the European Union in 2004, while an apparent equalization is taking place in Central-Eastern European countries; however this equalization is not coupled with convergence it rather results in a joint divergence.

The Central-Eastern European countries, with more or less success, have been taking the path of globalization-driven growth since the change of regime. Positive results have been achieved in the area of law and democracy; however negative results have become dominant that are summarized - not fully - below:

- the criterion of sustainability have not been achieved,

- income disparities have gradually increased,

- the proportion of poor people have increased within the society,

- although life expectancy at birth have slightly improved, the health state of population have deteriorated,

- rate of employment lags behind European average,

- unemployment have hectically changed over the past 20 years; the initial high values have decreased and a new deterioration took place in the past 5 years,

- $\quad$ the proportion of economically active people is low within the population (Boda-Scheiring, 2011).

Open unemployment was unknown in socialism, the employment rate was very high; each worker could feel his or her job safe. The socialist economy resulted in chronic shortage, one manifestation of which was the chronic unemployment. No matter how it affected efficiencies, workers enjoyed job safety; it came to a sudden end. The rate of employment considerably decreased and the open unemployment appeared. Unemployment practically traumatised the society. Job safety was lost. The unemployment rate illustrates the process of the regime change (Figure 4). The most hectic are the Slovakian and Polish curves that showed a 15\% drawback by the year 2008 . The reason of the relatively rapid reduction of unemployment rate (10-12\% point increasing) after the regim change in Slovakia and Poland was the industrial and corporative structural reconstruction which caused higher labour productivity. The unemployment rate data of Hungary, Slovenia and Czech Republic moved together in each period. Estonia, Latvia and Lithuania travelled on different routes, they not only completed the regime change fast and efficiently but were also able to treat the suddenly appearing unemployment efficiently. The economic world crisis (in 2008) could be instantly felt in the labour market as well; most of the states were unable to get out of the deep recession, although they introduced significant employment policy measures. Unemployment struck Latvia the most severely (Lipták, 2012). 


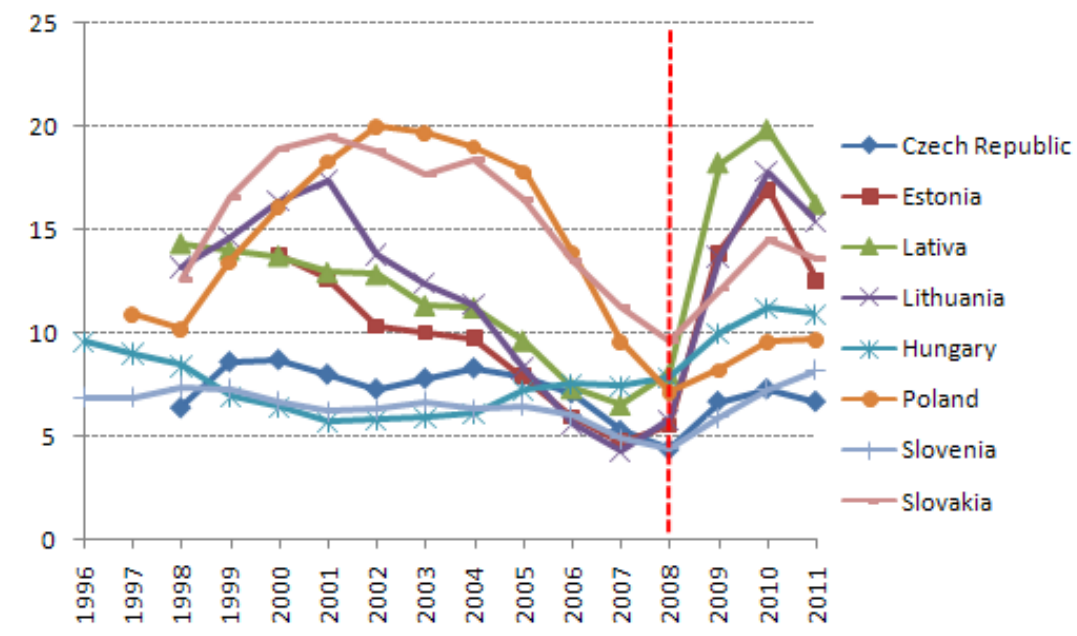

Figure 4. Unemployment rate (\%) between 1996-2011

Source: Own compilation based on Eurostat data.

The regime changing countries in question can be categorised into two groups in terms of the rate of employment (Figure 5) Poland, Slovakia and Hungary possessed lower levels of employment; whereas the rest of the countries got into higher categories. Studying the Estonian and Lativan employment policy could be a separate topic; they could reach the employment level of $70 \%$ as set out by the Lisbon Strategy, however, the crisis struck them as well and it broke the fast growing trend. The world economic crisis had caused a lowest employment rate in all analysed countries. The most relapse was in the Baltic countries, but after 2010 this situation had improved. The fast improvement of labour market due to the targeted employment policies. The employment rate in Hungary and in Poland were stagnate after the crisis till today.

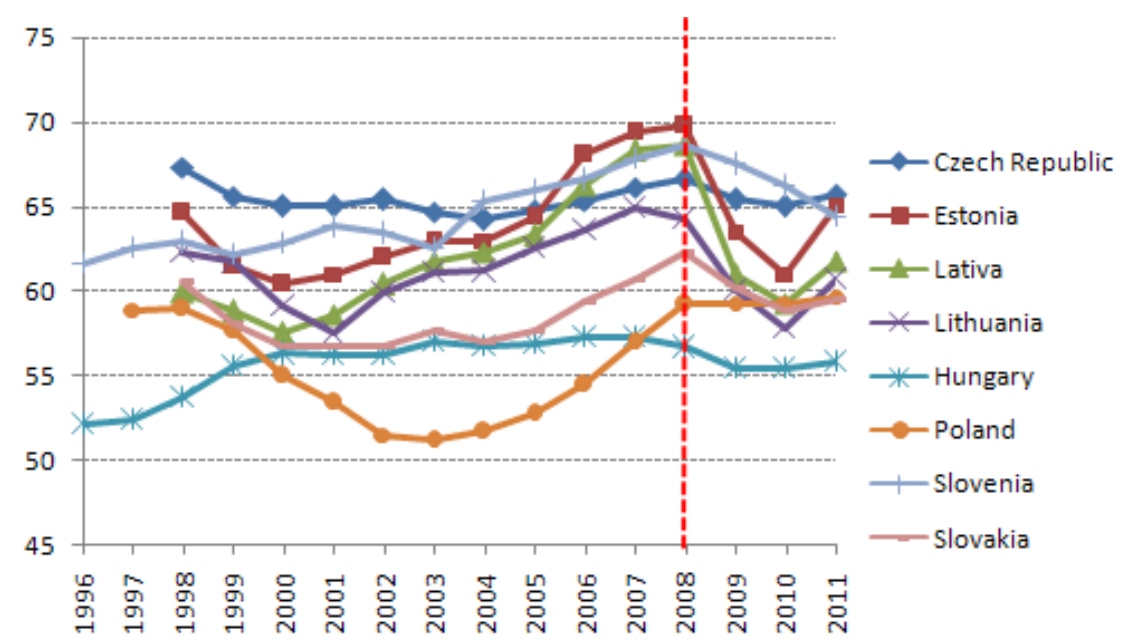

Figure 5. Employment rate (\%) between 1996-2011

Source: Own compilation based on Eurostat data.

\subsection{Methodology of HDI}

In the calculation of this index, a general formula is used, which is also applicable for each component of HDI. This formula is the following:

$$
I_{i}=\frac{X_{i}-X_{\min }}{X_{\max }-X_{\min }}
$$

Where 
$\mathrm{X}_{\mathrm{i}}$ is the actual value,

$\mathrm{X}_{\max }$ is the fixed highest value,

$\mathrm{X}_{\min }$ is the fixed lowest value of the variable.

The international literature has fixed the lowest and highest values for the calculation in the following way:

- life expectancy at birth: 25 and 85 years,

- adult literacy rate: $0 \%$ and $100 \%$,

- combined gross enrollment ratio: $0 \%$ and $100 \%$,

- GDP per capita (PPP): 100 US\$ and 40,000 US\$.

The HDI is calculated in the following steps:

1) First, the life expectancy rate is calculated $\left(I_{1}\right)$,

2) Then the adult literacy rate (a) and the combined enrollment index (b) are calculated $\left(\mathrm{I}_{2}\right)$. Finally, the knowledge gained in the education is calculated from the latter indices in the following way:

$$
I_{2}=\frac{2 a+1 b}{3}
$$

3) The next step is to calculate the modified GDP $\left(\mathrm{I}_{3}\right)$. In case of GDP, the logarithmic transformation, that maintains the differences in the order of size, is used (logarithmic calculation is used to represent the diminishing returns of the income growth in sub-index, and it also diminishes the differences in the absolute value of per capita GDP). Its formula is the following:

$$
I_{3}=\frac{\log y-\log y_{\text {min }}}{\log y_{\text {max }}-\log y_{\text {min }}}
$$

4) The last step is to calculate HDI using the following formula:

$$
H D I=\frac{I_{1}+I_{2}+I_{3}}{3}
$$

(Lipták, 2009).

\subsection{Result of HDI}

I was curious about what degree of regional disparity the Human Development Index (HDI) results in and to

\begin{tabular}{|c|c|c|c|c|c|c|c|}
\hline Regions & $\begin{array}{l}\text { HDI } \\
2004\end{array}$ & $\begin{array}{l}\text { HDI } \\
2009\end{array}$ & $\begin{array}{l}\text { difference } \\
\text { (\%point) }\end{array}$ & Regions & $\begin{array}{l}\text { HDI } \\
2004\end{array}$ & $\begin{array}{l}\text { HDI } \\
2009\end{array}$ & $\begin{array}{c}\text { difference } \\
\text { (\%point) }\end{array}$ \\
\hline Praha (CZ) & 0.690 & 0.717 & 0.027 & Malopolskie (PL) & 0.637 & 0.650 & 0.013 \\
\hline Strední Cechy (CZ) & 0.561 & 0.552 & -0.009 & Slaskie (PL) & 0.616 & 0.611 & -0.004 \\
\hline Jihozápad (CZ) & 0.599 & 0.611 & 0.012 & Lubelskie (PL) & 0.617 & 0.619 & 0.002 \\
\hline Severozápad (CZ) & 0.580 & 0.590 & 0.010 & Podkarpackie (PL) & 0.616 & 0.614 & -0.002 \\
\hline Severovýchod (CZ) & 0.597 & 0.608 & 0.011 & Swietokrzyskie (PL) & 0.620 & 0.614 & -0.006 \\
\hline Jihovýchod (CZ) & 0.624 & 0.645 & 0.021 & Podlaskie (PL) & 0.621 & 0.620 & -0.001 \\
\hline Strední Morava (XZ) & 0.601 & 0.613 & 0.013 & Wielkopolskie (PL) & 0.640 & 0.645 & 0.005 \\
\hline Moravskoslezsko (CZ) & 0.600 & 0.625 & 0.025 & Zachodniopomorskie (PL) & 0.629 & 0.615 & -0.014 \\
\hline Eesti (EE) & 0.614 & 0.623 & 0.009 & Lubuskie (PL) & 0.613 & 0.596 & -0.017 \\
\hline Latvija (LV) & 0.591 & 0.601 & 0.010 & Dolnoslaskie (PL) & 0.623 & 0.623 & -0.001 \\
\hline Lietuva (LT) & 0.614 & 0.629 & 0.014 & Opolskie(PL) & 0.600 & 0.603 & 0.003 \\
\hline Közép-Magyarország (HU) & 0.642 & 0.622 & -0.020 & Kujawsko-Pomorskie (PL) & 0.620 & 0.616 & -0.003 \\
\hline Közép-Dunántúl (HU) & 0.590 & 0.585 & -0.005 & Warminsko-Mazurskie (PL) & 0.621 & 0.614 & -0.007 \\
\hline
\end{tabular}
what extent it is related to the regional differences thus far in the Central-Eastern European region (Table 2).

Table 2. The result of HDI esetimation 


\begin{tabular}{|c|c|c|c|c|c|c|c|}
\hline Regions & $\begin{array}{l}\text { HDI } \\
2004\end{array}$ & $\begin{array}{l}\text { HDI } \\
2009\end{array}$ & $\begin{array}{c}\text { difference } \\
\text { (\%point) }\end{array}$ & Regions & $\begin{array}{l}\text { HDI } \\
2004 \\
\end{array}$ & $\begin{array}{l}\text { HDI } \\
2009\end{array}$ & $\begin{array}{r}\text { difference } \\
\text { (\%point) }\end{array}$ \\
\hline Nyugat-Dunántúl (HU) & 0.592 & 0.587 & -0.006 & Pomorskie (PL) & 0.625 & 0.634 & 0.009 \\
\hline Dél-Dunántúl (HU) & 0.589 & 0.593 & 0.004 & Vzhodna Slovenija (SI) & 0.663 & 0.615 & -0.048 \\
\hline Észak-Magyarország (HU) & 0.595 & 0.597 & 0.001 & Zahodna Slovenija (SI) & 0.666 & 0.693 & 0.027 \\
\hline Észak-Alföld (HU) & 0.591 & 0.610 & 0.019 & Bratislavský kraj (SK) & 0.674 & 0.717 & 0.043 \\
\hline Dél-Alföld (HU) & 0.588 & 0.594 & 0.006 & Západné Slovensko (SK) & 0.589 & 0.605 & 0.016 \\
\hline Lódzkie (PL) & 0.608 & 0.617 & 0.009 & Stredné Slovensko (SK) & 0.597 & 0.617 & 0.019 \\
\hline Mazowieckie (PL) & 0.655 & 0.663 & 0.007 & Východné Slovensko (SK) & 0.600 & 0.622 & 0.021 \\
\hline
\end{tabular}

Source: own work.

The change of HDI values (Figure 6) indicates a heterogeneous picture from year 2004 to 2009. The capital regions retained their strongest positions in both years; an improvement is observable in Estonia (HDI values in 2004: 0.614 and in 2009: 0.623) and Lithuania (HDI values in 2004: 0.614 and in 2009: 0.629) which is mainly due to the growth of incomes. The Human Development Index decreased in the case of some Polish regions (in Slaskie region the HDI value was 0.616 in 2004 and 0.611 in 2009 or in Swietokrzyskie region the HDI value was 0.620 in 2004 and decreased, it was 0.614 in 2009) which, having seen its extents, is due to a minor income change. In Hungary, the HDI values have decreased by 2009 in Central Hungary $(0.642$ in 2004 and 0.622 in 2009), Central Transdanubia (0.590 in 2004 and 0.585 in 2009) and Western Transdanubia (0.592 in 2004 and 0.587 in 2009) which was caused by a minor decrease in the rate of participants in education and a minor increase of incomes.
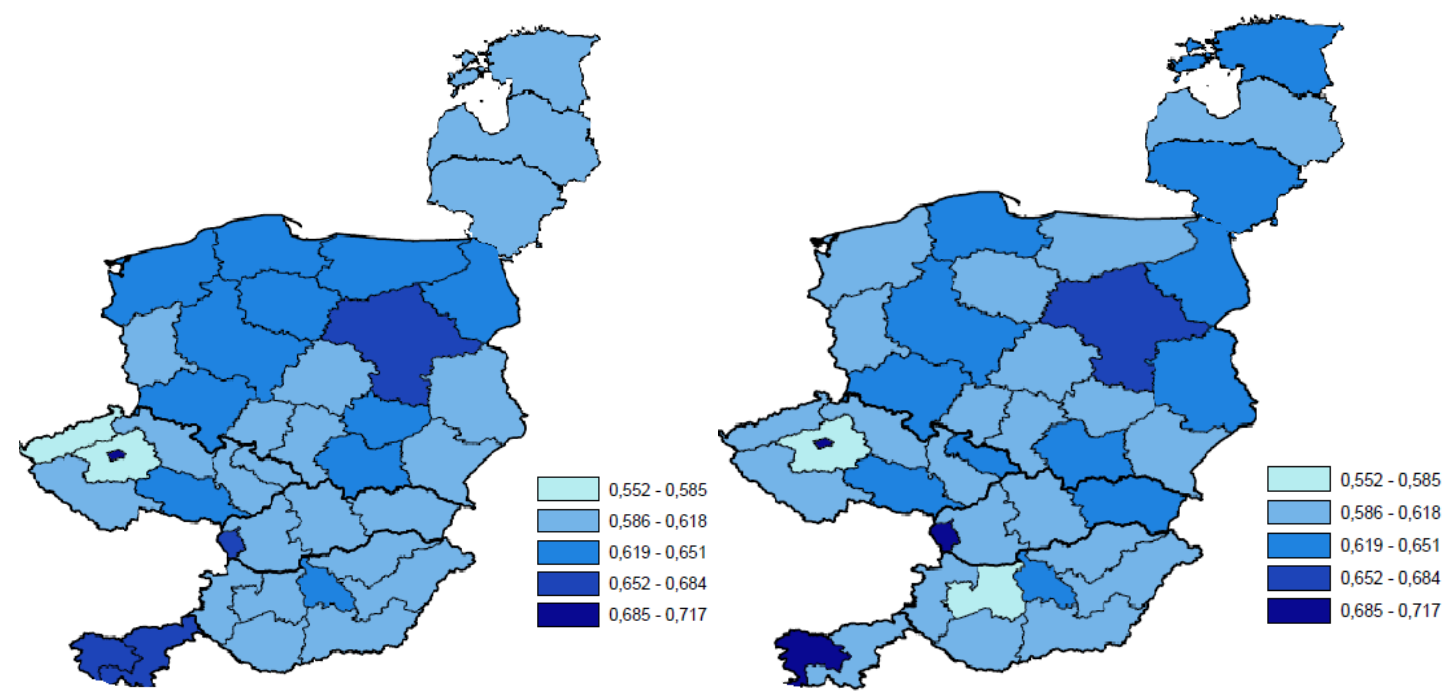

Figure 6. HDI values of Central-Eastern Europe at regional level (years 2004 and 2009)

Source: own compilation based on own calculation.

Thesis 2.b) The temporal change of HDI, apart from the improvement of human potential, brought about regional realignment in the labour market in Central-Eastern European regions. The former homogeneous state became much more unbalanced among the regions.

\subsection{Employment Policies of Central-Eastern European Countries}

The employment policy of the European Union significantly determines and sets limits on the employment-related objectives and efforts of the nation states (Table 3). 
Table 3. Employment policy of Central-Eastern Europe by countries

\begin{tabular}{|c|c|c|c|}
\hline Country & $\begin{array}{l}\text { Target values to be } \\
\text { achieved by } 2020\end{array}$ & Priorities & Length of NRP \\
\hline Czech & (1) rate of employment: & (1) applies active employment policy tools, (2) & 117 pages, with \\
\hline Republic & $\begin{array}{l}75 \% \text { (2) employment of } \\
\text { the , elderly: } 55 \% \text { (3) rate } \\
\text { of unemployment: n.a. }\end{array}$ & reducing young people's unemployment & $\begin{array}{l}12 \text { pages on } \\
\text { employment }\end{array}$ \\
\hline Estonia & $\begin{array}{l}\text { (1) rate of employment: } \\
75 \% \text { (2) employment of } \\
\text { the elderly: n.a. (3) rate of } \\
\text { unemployment: } 2,5 \%\end{array}$ & $\begin{array}{l}\text { (1) applies active employment policy tools, (2) } \\
\text { reducing unemployment, (3) improving quality of } \\
\text { life, (4) developing education }\end{array}$ & $\begin{array}{l}77 \text { pages, with } 5 \\
\text { pages on } \\
\text { employment }\end{array}$ \\
\hline Latvia & $\begin{array}{l}\text { (1) rate of employment: } \\
73 \% \text { (2) employment of } \\
\text { the elderly: n.a. (3) rate of } \\
\text { unemployment: n.a. }\end{array}$ & $\begin{array}{l}\text { (1) developing enterprises, (2) reducing } \\
\text { administrative burdens, (3) developing education, } \\
\text { (4) reducing unemployment, (5) supporting } \\
\text { mobility }\end{array}$ & $\begin{array}{l}60 \text { pages, with } 6 \\
\text { pages on } \\
\text { employment }\end{array}$ \\
\hline Lithuania & $\begin{array}{l}\text { (1) rate of employment: } \\
72,8 \% \text { (2) employment of } \\
\text { the elderly: } 53,4 \% \text { (3) rate } \\
\text { of unemployment: n.a. }\end{array}$ & $\begin{array}{l}\text { (1) increasing the number of economically active, } \\
\text { (2) developing education, ( } 3 \text { ) creating new jobs, } \\
\text { (4) modification of Labour Code for the creation } \\
\text { of a more efficient regulation system }\end{array}$ & $\begin{array}{l}42 \text { pages, with } 7 \\
\text { pages on } \\
\text { employment }\end{array}$ \\
\hline Hungary & $\begin{array}{l}\text { (1) rate of employment: } \\
75 \% \text { (2) employment of } \\
\text { the elderly: n.a. (3) rate of } \\
\text { unemployment: n.a. }\end{array}$ & $\begin{array}{l}\text { (1) reducing inactivity, (2) elimination of early } \\
\text { retirement, (3) increasing the employment of the } \\
\text { disabled, (4) creating a flexible labour market, (5) } \\
\text { developing the vocational training system, (6) } \\
\text { young people in focus, (7) increasing the } \\
\text { employment of the elderly }\end{array}$ & $\begin{array}{l}156 \text { pages, with } \\
27 \text { pages on } \\
\text { employment }\end{array}$ \\
\hline Poland & $\begin{array}{l}\text { (1) rate of employment: } \\
71 \% \text { (2) employment of } \\
\text { the elderly: n.a. (3) rate of } \\
\text { unemployment: n.a. }\end{array}$ & $\begin{array}{l}\text { (1) development of LLL, (2) increasing the } \\
\text { employment of the elderly ( } 50+\text { programs), (3) } \\
\text { increasing the employment of young people ( } 30- \\
\text { programs), (4) lower employment-related burdens }\end{array}$ & $\begin{array}{l}71 \text { pages, with } 4 \\
\text { pages on } \\
\text { employment }\end{array}$ \\
\hline Slovakia & $\begin{array}{l}\text { (1) rate of employment: } \\
72 \% \text { (2) employment of } \\
\text { the elderly: n.a. (3) rate of } \\
\text { unemployment: } 3 \%\end{array}$ & $\begin{array}{l}\text { (1) increasing the employment of young people, } \\
\text { (2) increasing the employment of disadvantaged } \\
\text { people, (3) developing education, (4) creating new } \\
\text { jobs }\end{array}$ & $\begin{array}{l}41 \text { pages, with } 3 \\
\text { pages on } \\
\text { employment }\end{array}$ \\
\hline Slovenia & \multicolumn{3}{|c|}{ The National Reform Program is not available either in Slovenian or English. } \\
\hline
\end{tabular}

Source: Own work based on NRP (2012) documents.

The analysed NRP documents indicate that most countries views the $75 \%$ rate of employment, accepted in the Europe 2020 Strategy, as an expected and attainable criterion. The Czech Republic and Lithuania displayed target values for the employment of the elderly, other countries did not specify it. The rate of unemployment was put forth by Estonia and Slovakia, with also unrealistically low target values (2.5-3\%). The priorities mainly include the use of active employment policy tools, although in most cases the tool to be applied is not specifically named. Most country see the future development of labour market in improving the quality of life, development of education, creation of new jobs and supporting mobility. At the same time, the amounts of support or the programs assigned were not mentioned in the documents.

We could observe the differences of target value, some countries (Czech Republic, Estonia, Hungary) would like to reach the $75 \%$ by the employment rate till 2020 . Between the employment policy tools appear the atypical employment forms (part-time job, telework) only in Hungary - it is astonish.

Thesis 3: Employment policy aims (National Reform Programs of 2012), at the level of Central-Eastern European countries, clearly follow the main guidelines of the Europe 2020 Strategy; they hardly build upon the peculiarities and labour market demands of the particular countries. Passive tools, among employment policy tools, are dominant in this group of countries. They responded to the economic crisis with the differentiated use 
of active and passive tools.

\section{Recommendations for Developing an Efficient Regional Employment Policy}

There is no experience of regionally differentiated employment policy in Central-Eastern European region. No examples can be found to this in Europe either, however, the existence of a regional employment policy with be reasonable. The summary of the author's recommendations for the establishment of a system of criteria to underpin a regional employment policy are listed below:

- A multi-channel employment policy would be reasonable in the long term that combines the traditional forms of employment and alternative solutions. A regional level decision is not sufficient for its realization, rather macro-level social-economic conditions have to be ensured, moreover an attitudinal change is essential. An increasing focus is placed on the application of non-traditional forms of employment due to the changing meaning of work-concept and also along with the change in the way of doing work. Future employment policies have to treat traditional and alternative forms of employment together.

- Regions having similar characteristics and similar labour market features should cooperate and act jointly in the European Union; joint asserting of interests and joint representation would bring significant results. The basis for the classification of regions into same types can be similar economic-social situation and same labour market conditions.

- A strategy capitalizing on internal features and naturally taking external processes into account should be formulated instead of continuously eliminating the European Union's employment policy. The National Reform Programs of Central-Eastern European countries were also studies that did not contain country-specific features, they rather followed, with more-or less differences, the aims of the Europe 2020 Strategy in terms of the target numbers.

- The issue of employment has to be addressed in a complex manner, it is necessary to coordinate tax-policy, educational policy and other sub-policies for enhancing efficiency.

- Developing an independent regional employment policy that sets up regional objectives and has independent measures and institutional system would be reasonable. Regional perspective is present in many areas in the European Union and this approach is getting increasingly reasonable in the case of employment and labour market as well. Regional employment policy would require independent system of measures and independent institutional system that would not be identical with the those applied in other regions of the country.

It can be seen that the concept of paid work is gradually loosing that of labour, which is a considerable problem. The re-definition of paid work is necessary because a significant part of the society has been excluded from the classical paid work. A smaller proportion of people of working age works in one of the traditional forms of employment, atypical forms of employment can be regarded as typical in the developed European countries, since they dominate. According to my opinion the atpical employment forms (part-time job, temporary job, telework) could solve partly the problem of the labour market.

\section{Acknowledgements}

This research was realized in the frames of TÁMOP 4.2.4. A/2-11-1-2012-0001.National Excellence Program Elaborating and operating an inland student and researcher personal support system convergence program. The project was subsidized by the European Union and co-financed by the European Social Fund.

\section{References}

Arendt, H. (1958). Vita Activa oder Vom tätigen Leben. Piper Press, München.

Aristotle. (1997). Nikomakhoszi etika (p. 455). Európa Kiadó, Budapest.

Boda, Zs., \& Scheiring, G. (2011). Globalization and development in the semi-periphery: Crisis and Alternatives (Globalizáció és fejlödés a félperiférián: válság és alternativák) (p. 208). Védegylet Kiadó, Budapest.

Castel, R. (1998). Deformations of the Social Issues - The Chronicle of the Paid Work (A szociális kérdés alakváltozásai - A bérmunka krónikája) (p. 453). Kávé Kiadó, Budapest.

Csoba, J. (2010). A Respectable Job: Full Employment: 21 chance or utopia century? (A tisztes munka: A teljes foglalkoztatás: a 21. század esélye vagy utópiája? - Kísérletek a munka társadalmának fenntartására s a jóléti állam alapvetö feltételeként definiált teljes foglalkoztatás biztositására) (p. 271). L'Harmattan Kiadó, Budapest. 
Deane, P. (1997). The Evolution of Economic Ideas (A közgazdasági gondolatok fejlödése) (p. 262). Közgazdasági és Jogi Könyvkiadó, Budapest.

Fazekas, K. (1997). Crisis and Prosperity on the Labour Market in Hungary, 1990-1996 (Válság és prosperitás a munkaerőpiacon - A munkanélküliség regionális sajátosságai Magyarországon 1990-1996 között). Tér és Társadalom, 11. évf. 4. Szám. pp. 9-24.

Galasi, P. (1994). Labour Economics (A munkaerőpiac gazdaságtana) (p. 153). Aula Kiadó, Budapest.

Lipták, K. (2009). Development or decline? - determination of human development at subregional level with the estimation of HDI. EU Working Papers, 12(4), 87-103.

Lipták, K. (2012). Labour market situation in Central-Eastern European countries - is there any hope for a better postition? RSA European Conference, final paper, Delft. Retrieved May 7, 2013, from http://www.regionalstudies.org/uploads/conferences/presentations/european-conference-2012/plenary-paper s/liptak.pdf

Malthus, T. R. (1944). Principles of Political Economy (A közgazdaságtan elvei tekintettel gyakorlati alkalmazásukra) (p. 463). Magyar Közgazdasági Társaság Kiadó, Budapest.

Marx, K. (1955). Capital: The Process of Production of Capital (A töke: A töke termelési folyamata) (p. 820). Kossuth Kiadó, Budapest.

Mátyás, A. (1969). Chapters in the History of Economic Thought (Fejezetek a közgazdasági gondolkodás történetéböl) (p. 259). Kossuth Kiadó, Budapest.

Nemes Nagy, J. (2005). Regional Analysis Methods (Regionális elemzési módszerek) (p. 284). Regionális Tudományi Tanulmányok 11.

Smith, A. (1959). The Wealthy of Nations (Nemzetek gazdagsága: E gazdaság természetének és okainak vizsgálata) (p. 413). Akadémiai Kiadó, Budapest.

Zalai, E. (1988). The Value of Work and Ownvalue (Munkaérték és sajátérték: Adalékok az értéknagyság elemzéséhez) (p. 219). Akadémiai Kiadó, Budapest.

\section{Copyrights}

Copyright for this article is retained by the author(s), with first publication rights granted to the journal.

This is an open-access article distributed under the terms and conditions of the Creative Commons Attribution license (http://creativecommons.org/licenses/by/3.0/). 